\title{
Case Study on Anti-retroviral Therapy and Deaf Clients in Taso Mulago Uganda Betty Kwagala*
}

Address: Counselling Department, Taso Mulago, P.O. Box 11485 Kampala

Email: Betty Kwagala* - kwagalabetty@yahoo.com

* Corresponding author

from 2005 International Meeting of The Institute of Human Virology Baltimore, USA, 29 August - 2 September 2005

Published: 8 December 2005

Retrovirology 2005, 2(Suppl I):PI2 doi:I0.I 186/I742-4690-2-SI-PI2

\section{Background}

TASO Mulago has started giving Anti-retroviral drugs to Persons with disabilities whose cd4 is bellow 200 since 2004. Un-fortunately in the Department of Medical and Counseling none knows sign language all the information concerning commitments, and Adherence, is given to care takers. A case study was done by the counselor in-charge of Disability affairs to find out if deaf clients are adhering to ARVS.

\section{Materials and methods}

Follow-up of Home visits to check adherence and commitments done by care takers. Pill count and talking to family members on the progress of the client since He/she started on Anti-retroviral drugs.

\section{Results}

Deaf clients because of language barrier they refuse to adhere to drugs especially TB drugs and Arvs because they don't know why they are taking them. All the information was given to caretaker who is not taking the drugs. Some disabilities are caused by the HIV Virus especially blindness, deafness, and permanent mental disorders in most clients who suffer from croptoccomengitis.

\section{Conclusion}

The Ministry of Health, HIV/AIDS Organizations to introduce sign Language in all HIV/AIDS Programs to benefit the deaf clients. Information to be brailed for the Blind. Rehabilitation programs for the Disabled Clients. 